\title{
Exploring the effectiveness of blended learning in interior design education
}

\section{Yasemin Afacan}

To cite this article: Yasemin Afacan (2016) Exploring the effectiveness of blended learning in interior design education, Innovations in Education and Teaching International, 53:5, 508-518, DOI: 10.1080/14703297.2015.1015595

To link to this article: https://doi.org/10.1080/14703297.2015.1015595

册 Published online: 24 Feb 2015.

Submit your article to this journal $\pi$

III Article views: 444

Q View related articles $\asymp$

View Crossmark data $\asymp$ 


\title{
Exploring the effectiveness of blended learning in interior design education
}

Yasemin Afacan*

Faculty of Art, Design and Architecture, Department of Interior Architecture \& Environmental Design, Bilkent University, Ankara, Turkey

\begin{abstract}
This study explores how blended learning can contribute to interior design students' learning outcomes, their engagement with non-studio courses and affect their learning achievements. Within the framework of the study, a blended learning experience was carried out in 'IAED 342 Building Performance' module at Bilkent University, Turkey. A total of 120 interior architecture students were surveyed about their experiences on five fields of instruction: (1) course design, learning material and electronic course environment; (2) interaction between students and instructor; (3) interaction with peers; (4) individual learning process; and (5) course outcomes. Frequency distributions, chi-square factor and regression analyses were calculated. Four blended learning factors were developed and their contribution to learning outcomes was analysed. The results showed that teaching both online and face-to-face can create an effective learning environment for non-studio classes, while contributing to a considerable value for the interior design education in terms of teaching process.
\end{abstract}

Keywords: blended learning; interior design education; effective learning; individual learning process

\section{Introduction}

Blended learning is becoming increasingly important in higher education, with the aims of better accomplishing course learning objectives, meeting students' changing needs and promoting effective learning. Research has revealed many advantages of blended pedagogy, such as pedagogic richness, flexibility and cost-effectiveness (Graham, 2004). With the move towards a more learner-centred and blended educational experience in higher education in Turkey as elsewhere, student learning has become more dynamic, interactive and motivated. Despite these advancements in teaching and learning, however, in the design education context students still have difficulty with motivation and self-direction in non-studio courses. In that sense, this study explores how blended learning can contribute to interior design students' learning outcomes, their engagement with non-studio courses and affect their learning achievements. To conduct the study and present the effectiveness of blended learning in a design context, a non-studio course, 'IAED 342 Sustainable Design for Interiors', was chosen as a case example, which has problems with students not engaging based on previous evaluation forms. Through this case example, the study tries to address the following four key themes: (i) blended learning in the interior design education in Turkey; (ii) creating a statistic framework to measure its

*Email: yasemine@bilkent.edu.tr 
effectiveness; (iii) how blended learning effects pedagogy and (iv) looking at what key motivators are needed to make it work. Statistical analyses showed that clarity of goals and structure of a module plays a critical role in the effectiveness of a blended learning environment.

There are many definitions of blended learning, also called hybrid or mixed learning. According to Garrison and Kanuka (2004), blended learning is a combination of face-to-face (f2f) classes with online teaching. While some studies define courses in which a substantial portion (24-75\%) is delivered online as blended learning, others consider blended learning as any combination of $\mathrm{f} 2 \mathrm{f}$ and online instruction. Curtis, Graham, Cross, and Moore (2005) highlighted the three most common definitions of blended learning: (i) combining instructional modalities; (ii) combining instructional methods and (iii) combining online and $\mathrm{f} 2 \mathrm{f}$ instruction. The common point in all these definitions is blending the best features of $\mathrm{f} 2 \mathrm{f}$ teaching with web-supported online technology (Graham, 2004; Jones \& Lau, 2010; Macdonald, 2008).

The success of blended learning, then, is not solely based on a simple integration of classroom teaching with digital media (De George-Walker \& Keeffe, 2010). Using blended learning resources may produce changes in learning patterns and practices (López-Pérez, Pérez-López, \& Rodríguez-Ariza, 2011), and thus its implications for critical education contexts should be analysed. The interior design context, for example, is based on design studio education as a core process of 'learning by doing' (Schon, 1981) and embraces numerous forms of representations (visual, verbal, tactile and written), assessment types (design reviews, juries and studio work) and teaching methods (desk/individual critiques, group tutorials and lectures). Different from other disciplines, design studio education is rich in teaching, learning and communication potential, and thus may benefit from combining $\mathrm{f} 2 \mathrm{f}$ classes with e-learning modules in a number of ways, allowing instructors and students to enjoy the possibilities of new information and communication technologies (ICTs).

\section{Educational context: interior design education}

In interior design education, it is essential to gain knowledge about technical, social, cultural and technological issues alongside studio teaching. Design studios are assumed to be the core of the curriculum in interior design education, where designing is a matter of analysing, synthesising, evaluating and presenting ideas for a creative solution (Demirkan \& Afacan, 2012). Each studio project generally requires studying precedents of architectural space and form, using of appropriate materials and construction techniques and presenting of drawings and 3D models. However, despite huge advancements in design teaching and learning, students have difficulty motivating and directing themselves in non-studio courses. According to the Eberly Center for Teaching Excellence in Carnegie Mellon University (2012), there are three main reasons for low motivation: (i) students do not see the relevance of the material to their studio practice; (ii) students have a naïve conceptualisation of creativity and/or (iii) students are not confident they have the skills required for nonstudio classes. With these factors in mind, and different from other studies in the design literature (which have mainly investigated blended learning's potential as a communication tool (Martens \& Achten, 2007), we propose in this study that the blended learning environment can overcome the above three challenges in the Turkish context. Few institutions in Turkey provide faculty members developmental 
aid, technical support or training for blended and/or online learning (Ocak, 2011). This study is thus a unique effort by the Department of Interior Architecture and Environmental Design at Bilkent University at being the first to create a social learning environment in a non-studio class through blended learning.

\section{Methodology}

\section{The setting and participants}

This study took place at Bilkent University, Department of Interior Architecture and Environmental Design. The curriculum is organised around studios which prepare future designers to deal progressively with larger and more complex interiors. The 'IAED 342 Sustainable Design for Interiors' module, with a focus on sustainable indoor environmental quality, is one of the department's non-studio courses, and is required for third-year interior architecture students in the spring semester. Within the framework of this study, this course was redesigned and taught in spring 2011 and spring 2012 to address the learning challenges mentioned above. In 2011, 80 third-year interior architecture students enrolled (11 male, 69 female) and in 2012, 120 students (26 male, 94 female) enrolled. In both semesters, the course was conducted in two class sections that included an equal number of students.

The reasons we chose the IAED 342 module for this study are as follows: (i) course evaluation forms for the module over the last ten years showed that most students were not engaged with the course content and could not stimulate interest in the subject; (ii) students had difficulty linking the gained knowledge into their studio projects, although they found the topics quite important for interior design practice and (iii) the course grade point average (gpa) was usually low and students learned passively, taking lecture notes. To overcome these challenges, blended learning was incorporated into the course for four hours per week (two hours per class) over a period of 15 weeks. The pedagogical strategies applied in this course are based on f2f classes with e-learning modules, where the instructor and the students could enjoy the possibilities of new ICTs.

\section{Course overview}

Moore (1989) maintains that in the field of online education, there are three types of interaction: learner-learner, learner-content and learner-instructor. These interaction activities in this study, their contribution to the course grade and their intended aims are illustrated in Table 1. The seven-week theoretical portion of IAED 342 consisted of seven topics, which were first presented online by groups of six students, later discussed $\mathrm{f} 2 \mathrm{f}$ in the two-hour discussion class and finally taught by the instructor in the next two-hour f $2 \mathrm{f}$ class. In the introductory lecture, the objectives and learning outcomes of the course and the aim of blended learning were clearly explained. Students formed presentation groups and topics were shared among the groups. The students had one week to prepare each week's presentation, which were then uploaded into Moodle. After the presentation, the rest of the class and the instructor had one week to study the topic, critically review it online and grade it. Class and instructor feedback were posted through forum discussions. The grade was the result of the mean of the instructor's grade and the classmates' grades. Grades were posted online, but anonymously. Individual grades given by students were not visible; the group could only see the overall grade given by the class and the instructor's grade, 
Table 1. Blended learning factors with their loadings.

\begin{tabular}{|c|c|c|c|c|c|}
\hline \multirow{2}{*}{ Names } & & \multicolumn{4}{|c|}{ Loadings } \\
\hline & & 1 & 2 & 3 & 4 \\
\hline \multirow{8}{*}{$\begin{array}{l}\text { Satisfaction and engagement } \\
\text { derived from acquired skills } \\
\text { and competences }\end{array}$} & $\begin{array}{l}\text { I acquired knowledge and skills in the } \\
\text { subject }\end{array}$ & .732 & .360 & .360 & .332 \\
\hline & $\begin{array}{l}\text { I acquired skills in collaboration and } \\
\text { group working }\end{array}$ & .712 & .389 & .340 & .371 \\
\hline & $\begin{array}{l}\text { I acquired skills on how to implement } \\
\text { technical information into practical design } \\
\text { issues }\end{array}$ & .676 & .452 & .320 & .311 \\
\hline & $\begin{array}{l}\text { Both online and face-to-face learning } \\
\text { environment of the course helped me to } \\
\text { engage in a process of continuous learning }\end{array}$ & .671 & .373 & .372 & .257 \\
\hline & My interest in the subject was stimulated & .663 & .424 & .312 & .226 \\
\hline & I was satisfied with the amount of time & .650 & .190 & .455 & .268 \\
\hline & I engaged in the active learning process* & .578 & .399 & .227 & .312 \\
\hline & $\begin{array}{l}\text { I acquired skills on how to integrate } \\
\text { different course contents to the design } \\
\text { studio }\end{array}$ & .555 & .413 & .391 & .180 \\
\hline \multirow[t]{4}{*}{ Quality of teaching material } & $\begin{array}{l}\text { The online teaching material helped me to } \\
\text { learn during the face-to-face activities }\end{array}$ & .303 & .795 & .345 & .205 \\
\hline & I am satisfied with face-to-face material & .394 & .756 & .224 & .253 \\
\hline & $\begin{array}{l}\text { The relationships between the online } \\
\text { materials and course content were clarified } \\
\text { by the instructor }\end{array}$ & .293 & .716 & .414 & .232 \\
\hline & $\begin{array}{l}\text { I am satisfied about the design of online } \\
\text { teaching material** }\end{array}$ & .380 & .658 & .199 & .357 \\
\hline \multirow[t]{5}{*}{$\begin{array}{l}\text { Independence in the learning } \\
\text { process }\end{array}$} & $\begin{array}{l}\text { The level of technology knowledge of the } \\
\text { instructor is sufficient }\end{array}$ & .184 & .264 & .713 & .209 \\
\hline & $\begin{array}{l}\text { The course provided me flexibility in } \\
\text { learning time*** }\end{array}$ & .477 & .196 & .691 & .213 \\
\hline & $\begin{array}{l}\text { The course allowed me to learn at my } \\
\text { own pace }\end{array}$ & .510 & .191 & .667 & .208 \\
\hline & $\begin{array}{l}\text { The instructor was easily accessible } \\
\text { whenever she is needed }\end{array}$ & .281 & .308 & .635 & .248 \\
\hline & $\begin{array}{l}\text { The teacher helped me to link the } \\
\text { knowledge from the course into other } \\
\text { courses }\end{array}$ & .456 & .337 & .557 & .280 \\
\hline \multirow[t]{3}{*}{$\begin{array}{l}\text { Clarity of the goals and } \\
\text { structure }\end{array}$} & $\begin{array}{l}\text { The objectives and learning outcomes of } \\
\text { the course explained clear and in detail }\end{array}$ & .288 & .287 & .314 & .816 \\
\hline & $\begin{array}{l}\text { The structure of the course was organised } \\
\text { clearly }\end{array}$ & .303 & .302 & .304 & .799 \\
\hline & $\begin{array}{l}\text { The online platform was appropriate for } \\
\text { the course purpose }\end{array}$ & .432 & .363 & .396 & .527 \\
\hline
\end{tabular}

Note: The bold values represent higher association between two variables. Thus, the study defined factor loadings in excess of .55 as suitable and excluded factor loadings below .55.

*A statistically significant relationship between the course grade and being actively engaged in the learning process $\left(\chi^{2}=76.214, d f=12, \alpha=.00\right)$.

**A statistically significant relationship between student outcome (course grade and design studio grade) and student satisfaction $\left(\chi^{2}=69.242, \mathrm{df}=16, \alpha=.00\right)$.

***A statistically significant relationship between flexibility in learning duration and student outcomes: a lower dropout rate and higher exam marks occurred in both the studio and the non-studio course $\left(\chi^{2}=\right.$ $78.810, d f=12, \alpha=.00)$.

which was calculated by the system. This peer-review assessment process contributed $5 \%$ to the overall grade of each student, i.e. a student who participated in all the online assessment processes received the whole $5 \%$.

In the practical portion of the course, each student was to design the indoor environmental quality of his/her own project and work individually with a representative 
from the leading supplier of innovative and sustainable air conditioning technology worldwide since 1951. There was a guest tutor collaboration over seven weeks, with three weeks $\mathrm{f} 2 \mathrm{f}$ and four online. In the first three weeks, the guest lecturer gave detailed tutorials on built examples and responded to students' questions on design criteria, equipment selection. After the end of each lecture, informal class discussions occurred with the tutor online and $\mathrm{f} 2 \mathrm{f}$, where the students could receive feedback, ask questions and share ideas. The last four weeks entailed online critiques, group discussions and one video conference among the students, guest tutor and instructor. Students obtained feedback, redesigned their cooling and heating systems according to feedback and chose appropriate air conditioning equipment. The six projects that best achieved interior architecture integration with mechanical design were chosen to be exhibited in different branches of the firm throughout Europe. The idea of getting an award motivated students very much and increased the interest in the course throughout the semester. It should be noted that according to the students, the attraction was not the award itself, but rather the honour of receiving an award in front of the faculty and their peers.

\section{The procedure}

The first year (spring 2011) of the revised course was considered a pilot study for this research. The aim of this piloting process was to avoid inappropriate instruction and establish the best implementation of blended learning for the course. Unstructured interviews and semi-structured questionnaires were conducted at different times during the semester for a formative and summative course evaluation. According to the feedback, most students (76 of 80 ) were highly engaged with the course and all students had a positive attitude towards the blended learning implementation.

The findings of the pilot study were used to finalise the course delivery method of 2012, and the experiences and/or expectations that students considered important in the 2011 interviews and questionnaires were included in the course evaluation for 2012. Thus, based on the pilot study, a survey instrument (a structured questionnaire format with closed-ended questions) with a comprehensive list of 32 items was developed to gather data. The questions were systemised and grouped under five categories, with reference to Ehlers (2004) five fields of instruction: (i) course design, learning material and electronic course environment; (ii) interaction between students and instructor; (iii) interaction with peers; (iv) the individual learning process and (v) course outcomes. In the survey, students were asked to rate the importance level of each item listed under each of the five categories on a scale of 1-5, (1 being 'least important' and 5 'most important' for the first three categories, and 1 being 'strongly disagree' and 5 'strongly agree' for the remaining two categories). Next, they were asked to mark the appropriate boxes to identify how important each of a number of features is in understanding, using and experiencing the blended learning environment.

\section{Findings}

\section{Student responses to the blended learning environment}

Students considered this course a useful blended learning experience. Regarding the blended learning environment, all students were satisfied with the learning management of the course as a whole (the highest mean $=4.6020$ ). The findings revealed 
that all 67 successful students out of 120 students (those with both a course and design grade above 2.70 over 4.00 ) felt that the positive outcomes of blended learning occurred in terms of the diverse interactions among student, instructor and content. Focus group interviews revealed that 108 of 120 students noted the importance of an effective learning environment, enabling learners to successfully use the material presented along with collaboration activities.

Students gave higher scores for the following three categories: (i) communication with others online (item 20, mean $=4.2551$; item 19 , mean $=4.0204$ ); (ii) flexibility in the learning process (item 24 , mean $=4.1082$; item 23 , mean $=4.0286$ ) and (iii) being active during the course (item 32 , mean $=4.1633$ ). By communicating with others online, students could share ideas, collaborate, discuss and make use of each others' experiences. They stated that especially for juried work, the more critical feedback they had with each other, the more successful projects they had. Through group presentations and peer-review assessments in $\mathrm{f} 2 \mathrm{f}$ and discussion groups online, 92 students stated that they had the chance to experience different ideas in design. However, 28 students had very negative attitudes to group work because of (i) loss of ownership; (ii) conflicting ideas; (iii) organisation problems and (iv) decreased quality of work. Thus, item 28 , 'I acquired skills in collaboration and group work' received the lowest mean (3.4286). Ten of 28 students stated that group work decreased their learning performance because they lost ownership of the project. Eighteen students complained that there were organisation problems, conflicting ideas and disagreements regarding solution alternatives.

You can learn something different and better understand the project with the help of brainstorming. (Student 15)

You can enjoy the project more while sharing your friends' ideas and experiences. (Student 32)

The nature and content of interior/architecture education is based on various solutions. Thus, there is not only one solution domain underlying studio teaching, rather, there are a number of different ways to approach a design problem, each of which could be accepted as relevant as long as the technical considerations are correct. For this reason, differences in students' ideas occur and can sometimes be difficult to deal with. To avoid this problem, the instructor tried to hint the nature of architectural design within the $\mathrm{f} 2 \mathrm{f}$ and online discussions.

Regarding flexibility, all students found it very beneficial to be able to access all the course information, news, discussion and data online. Forty-eight students stated that this format allows better opportunities for student learning. Seventy-one students noted that because access was no longer restricted by a timetable, the course allowed them to learn at their own pace. However, 19 students highlighted the significance of $\mathrm{f} 2 \mathrm{f}$ tutorials. These students felt that flexibility alone was not always sufficient to achieve learning outcomes and fully understand the topics; they indicated they sometimes need instructor support and the constraint of a timetable, which helps them manage their responsibilities.

I can easily access the course on and off campus through the internet. (Student 102)

It is great to go back and study ... the course material whenever we need to. (Student 3)

Regarding being active during the course, more than half the students (72 of 120) strongly agreed and 46 students agreed that they engaged in the active learning 
process. Only two students disagreed, because they had difficulty with the combination of $\mathrm{f} 2 \mathrm{f}$ and online instruction; they felt that the two did not match well. Sixty-three students stated that the online and $\mathrm{f} 2 \mathrm{f}$ classes provided an enjoyable and sociable active learning experience. Moreover, ten of 120 students stated that they were reluctant to speak in front of a class in non-studio courses, but in the blended learning environment of this course they actively participated in learning, assessing and discussing. According to 100 students, this process helped develop their confidence.

I felt responsible to the course, so I forced myself to learn and work a lot. (Student 51)

It makes us listen to other ideas, tutorials, and contribute actively to discussions. I think it is good for future life. (Student 22)

\section{Developing blended learning factors for non-studio classes and their regression analyses}

Before carrying out factor analysis, we first examined the survey instrument to determine whether there were any items creating floor and/or ceiling effects (i.e. items at the extreme ends of the scale). As the scale in this study is 5, items below 1.5 and above 4.5 are regarded as being at the extreme ends, and thus should be eliminated. There were no items at the extreme ends. Second, we calculated the strength of the correlations among the survey items through exploratory factor analysis, which helped identify common issues and exclude unrelated ones. We calculated Pearson product-moment correlations of the response scores and constructed a correlation matrix. Items having a correlation score lower than .30 were not preferred for the study, because for a useful statistical approach, a correlation coefficient of 1.00 indicates a perfect association between two variables (Argyrous, 2005). In the study, ten correlations between item response scores were lower than .30 , so were eliminated. Because a ratio as low as four subjects per variable is appropriate for distribution (Bentler \& Chou, 1987), the study sample size (120 participants) can be considered as adequate in terms of sample representativeness and estimate accuracy.

The study defined factor loadings in excess of .55 as suitable and excluded factor loadings below .55. We calculated total variance of factors, which 'shows all the factors extracted from the analysis along with their eigenvalues, the percentage of variance attributable to each factor, and the cumulative variance of the factor' (Mieczakowski, Langdon, \& Clarkson, 2010, p. 138). Factor analysis resulted in a four-factor solution that accounted for $74.121 \%$ of the total variance. Thirty-two items had $74.121 \%$ variances in common, so they correlated highly with four common themes; each theme was considered to be a factor scale (Table 1).

Factor 1, Satisfaction and engagement derived from acquired skills and competences, is related to the quality of learning outcomes. It could be concluded that the greater satisfaction and engagement in the learning process achieved from the blended learning activities resulted in higher course outcomes. This is in line with López-Pérez et al. (2011) study: students' greater motivation from f2f classes and e-learning activities positively affects course outcomes in terms of final marks. In this study, course outcome does not mean only the final mark, but also the level and quality of acquired knowledge and skills, and the student's ability to link the course information into his/her studio project. 
Factor 2, Quality of teaching material, refers to how well the course materials (both $\mathrm{f} 2 \mathrm{f}$ and online) inspire the best from students and make the content interesting to them. The online and $\mathrm{f} 2 \mathrm{f}$ classes complement each other; how course content is communicated in the online teaching materials should be the same as it is in the $\mathrm{f} f \mathrm{f}$ classes. This factor also assesses the instructor's teaching materials, as it is important that the material keeps students on topic.

Factor 3, Independence in the learning process, includes variables related to flexibility in the learning process and accessibility of the instructor during this process. To achieve the goals of blended learning, an instructor must abandon his/her traditional content-provider role and adopt a mentoring, coaching and advising role in the learning process, which is a powerful means of meeting student needs (Kultur \& Williams, 2011, p. 21). Faculty must have a high level of expertise in the online learning environment and exhibit careful planning and organisation.

Factor 4, Clarity of the goals and structure, is composed of three variables closely related to how well the instructor structured the course content, outcomes and learning platform. All the objectives, learning outcomes, guidelines and information needed to achieve successful outcomes should be clear and integrated in one place online (Ginns \& Ellis, 2007). Prior to course implementation and/or moving to a blended learning environment, the following key issues must be clearly and systematically defined: student learning outcomes, course content, learning and teaching strategies, assessment and course structure (Kultur \& Williams, 2011).

The study also investigated which learning outcomes (of four achievement variables: course grade, design grade, student's gpa and student's participation) contribute to the blended learning factors. We performed multiple regression analysis with the four factors as independent variables and the four achievement variables as dependent variables.

The course grade was affected positively by three variables: Factor 1 (satisfaction and engagement derived from acquired skills and competences; $\beta=.467, p<.00$ ); Factor 2 (Quality of teaching material; $\beta=.172, p<.00$ ) and Factor 4 (clarity of the goals and structure; $\beta=.294, p<.00$ ). Three variables contributed positively to the design grade: Factor 2 (quality of teaching material; $\beta=.254, p<.00$ ); Factor 3 (independence in the learning process; $\beta=.250, p<.00$ ) and Factor 4 (clarity of the goals and structure; $\beta=.349, p<.00$ ). Two variables were positively related to the student's gpa: Factor 3 (independence in the learning process; $\beta=.385, p<.00$ ) and Factor 4 (clarity of the goals and structure; $\beta=.343, p<.00$ ). Regarding the student's participation in the course, only one variable contributed positively: Factor 4, (clarity of the goals and structure; $\beta=.456, p<.00$ ). Factor 4 is obviously a critical variable, playing a significant role in all four achievement variables.

\section{Discussion}

The results of the study showed that blended learning effectively contributes to interior design students' learning outcomes, engagement with non-studio courses and is related to students' success of their studio projects. The developed blended learning factors for non-studio courses create a social learning environment while increasing the quality and flexibility of the educational content of the delivered module. It is possible to discuss the results from two points of view: (i) learning effectiveness and (ii) the teaching process. 
According to Maki, Maki, Patterson, and Whittaker (2000), learning effectiveness is influenced by the degree of satisfaction with learning and learning achievements. In the study, the degree of satisfaction with learning in the interior design education context can be defined by the following criteria: implementation of theoretical knowledge gained from non-studio courses into practical design issues in studio courses, engagement in the process of continuous learning, engagement in the active learning process and interest stimulation. As many students reported, as long as a strong link between the design studio and other courses could be established, they could learn effectively; this link is also closely related to their learning achievements. As stated in the above section, learning achievement is defined by course grade, design grade, student's gpa and student's participation. Online environments and e-learning activities not only support the effectiveness of the learning process, but also create an active learning platform. This platform is particularly important in design education contexts, where students are required to collaborate within a social community and weigh their knowledge, skills and views against those of others. Moreover, a responsive and social learning environment formulated with varying degrees of instruction methods and mediated with diverse knowledge from different aspects can improve the quality of design teaching.

Combining online and $\mathrm{f} 2 \mathrm{f}$ instruction can create considerable value for interior design education. As proven by many researchers, poor teaching tends to result in a lower quality of learning (Ginns \& Ellis, 2007). In this study, teaching is defined as a multi-parameter task, which cannot be solved only by the instructor. Assessment, content, teaching material and structure of a course are four critical components of this process. They should be designed in a clear and systematic way to investigate the relationships between the 'part' and the 'whole'; each non-studio course is part of the whole design process, which is carried out in studios. Content is differentiated from teaching material by its focus on the syllabus, which is an outline and topics covered within a module. Assessment should be aligned to the content, teaching material and structure of the course, which exhibit a balance regarding the learning outcomes. According to Ocak (2011), "varied teaching patterns and technologybased teaching can be major obstacles to successful implementation of blended courses' (p. 695); therefore, easy-to-use technology and an instructor who knows how to use it well are imperative. To eliminate any misunderstanding, there should be continuous communication between students and instructor.

\section{Conclusion}

The results of this study encompass important considerations for the design of blended learning environments. Clarity of course content and structure proved to be significant for students to achieve learning outcomes and be successful in other contexts of their design education. In this respect, instructors who plan to teach online face more challenges and difficulties than in traditional classroom teaching. The study also analysed student suggestions for making the process of blended learning more effective, and two main themes emerged. The first theme was to integrate such processes in other curricular courses so students are better prepared for real-life situations. The second theme was to use the technology to expand the blended learning process, such as collaborating with other international firms in an online learning environment, accessing a wealth of information and increasing interaction. According to Vygotsky's social development theory, learning does not happen in isolation. 
A high level of interaction helps increase positive attitudes towards learning, satisfaction with learning, student engagement and motivation, resulting in higher achievement (Garrison, 1990). Although high achievement correlation with high engagement is likely in any learning situation, in this design it can be differentiated by creating the active and social learning environment, where less extravert students are encouraged to contribute in online discussion.

We note that the study does have limitations. The sample size is small and the study area is limited to the Turkish context; thus it is not possible to generalise the results. Further research could include more participants from different years of interior architecture education. A future goal for the author may be to conduct a comparative cultural study with other design schools to focus more on the importance of blended learning effectiveness.

\section{Notes on contributor}

Yasemin Afacan is an assistant professor in the Department of Interior Architecture and Environmental Design, at Bilkent University, Ankara, Turkey. Following the completion of her $\mathrm{PhD}$ on universal kitchen design in Bilkent University in 2008, she worked as a lecturer in Architecture in Queens University Belfast, UK. Her research is concerned with sustainability, housing studies, CAD, inclusive design and architecture education. She teaches undergraduate-level courses on interior design and sustainable design. Her works have been presented in international refereed journals, conference proceedings, and book chapters: such as Applied Ergonomics, Journal of Engineering Design, Design Studies, Open House International, The Design Journal, including two book chapters in the Designing Inclusive Futures and Systems from Springer.

\section{References}

Argyrous, G. (2005). Statistics for research. London: Sage.

Bentler, P. M., \& Chou, C. P. (1987). Practical issues in SEM. Sociological Methods and Research, 16, 78-117.

Curtis, J. B., Graham, C. R., Cross, J., \& Moore, M. G. (2005). The handbook of blended learning: Global perspectives, local designs. Zurich: Pfeiffer.

De George-Walker, L., \& Keeffe, M. (2010). Self-determined blended learning: A case study of blended learning design. Higher Education Research and Development, 29, 1-13.

Demirkan, H., \& Afacan, Y. (2012). Assessing creativity in design education: Analysis of the creativity factors in the first year design studio. Design Studies, 33, 262-278.

Eberly Center for Teaching Excellence in Carnegie Mellon University. (2012). Learning and teaching principles [online]. Retrieved from http://www.cmu.edu/teaching/

Ehlers, U. (2004). Quality in e-learning. The learner as a key quality assurance category. European Journal of Vocational Training, 29, 3-15.

Garrison, D. R. (1990). An analysis and evaluation of audio teleconferencing to facilitate education at a distance. The American Journal of Distance Education, 4, 13-24.

Garrison, D. R., \& Kanuka, H. (2004). Blended learning: Uncovering its transformative potential in higher education. The Internet and Higher Education, 7, 95-105.

Ginns, P., \& Ellis, R. (2007). Quality in blended learning: Exploring the relationships between on-line and face-to-face teaching and learning. Internet and Higher Education, $10,53-64$.

Graham, C. R. (2004). Blended learning systems: Definition, current trends, and future directions. In C. J. Bonk \& C. R. Graham (Eds.), The handbook of blended learning: Global perspectives, local designs (pp. 3-21). Zurich: Pfeiffer.

Jones, N., \& Lau, A. M. S. (2010). Blended learning: Widening participation in higher education. Innovations in Education and Teaching International, 47, 405-416.

Kultur, C., \& Williams, E. (2011). Guidelines for using blended learning in your classes. Ankara: Meteksan Bilkent University Press. 
López-Pérez, M. V., Pérez-López, C., \& Rodríguez-Ariza, L. (2011). Blended learning in higher education: Students' perceptions and their relation. Computers and Education, 56, 818-826.

Macdonald, J. (2008). Blended learning and online tutoring (2nd ed.). Hampshire: Gower.

Maki, R. H., Maki, W. S., Patterson, M., \& Whittaker, P. D. (2000). Evaluation of a webbased introductory psychology course: I-learning and satisfaction in on-line versus lecture courses. Behavior Research Methods of Instruments and Computers, 32, 230-239.

Martens, B., \& Achten, H. (2007, September). Do you Moodle? Experiences with a virtual learning environment. Proceedings of the Education and Research in Computer Aided Architectural Design in Europe (ECAADE) 2007 Conference, Frankfurt/Wiesbaden, Germany, pp. 153-160.

Mieczakowski, A., Langdon, P. M., \& Clarkson, J. (2010). Investigating designers' cognitive representations for inclusive interaction between products and users. In P. Langdon, J. Clarkson, \& P. Robinson (Eds.), Designing inclusive interactions (pp. 133-145). London: Springer.

Moore, M. (1989). Editorial: Three types of interaction. The American Journal of Distance Education, 3, 1-7.

Ocak, M. A. (2011). Why are faculty members not teaching blended courses? Insights from faculty members. Computers and Education, 56, 689-699.

Schon, D. (1981). Learning a language, learning to design. Architectural Education Study, 1, $339-471$. 